\title{
Dryness of the Oral Cavity in the Salivary Status of Overweight Women
}

\author{
Ameta Primasari, Keristian Perlindungan Hulu \\ Department of Oral Biology, Faculty of Dentistry, University Sumatera Utara, Medan, Indonesia
}

Email address:

ameta.primasari@usu.ac.id (A. Primasari)

\section{To cite this article:}

Ameta Primasari, Keristian Perlindungan Hulu. Dryness of the Oral Cavity in the Salivary Status of Overweight Women. International Journal of Homeopathy \& Natural Medicines. Vol. 5, No. 2, 2019, pp. 50-53. doi: 10.11648/j.ijhnm.20190502.11

Received: June 3, 2019; Accepted: August 26, 2019; Published: September 30, 2019

\begin{abstract}
Overweight is a public health problem that may raise general health complication. Excess weight people often have complaints about the state of oral health especially salivary secretions. Saliva is very important for human life, not only for mastication digesting food and also cleaning and lubricating the oral cavity. reduced salivary production can increase the prevalence of dental caries. It is known that people who are overweight have teeth with numbers of caries. it is suspected that the complaint of people who have overweight, may have feeling of dryness in the oral cavity. this can be the cause of poor oral hygiene. The aim of this research to know the difference of average amount status of saliva in women with normal weight, overweight and obesity. This research analitic study with cross-sectional design. Retrieval of unstimulated saliva was done with the method of draining at 60 persons: 20 persons normal weight, 20 persons overweight and 20 persons obesity. Salivary $\mathrm{pH}$ measurements using Hanna instruments and measurement of flow rate and volume using digital scales. The result of Kruskal-Wallis test showed that different significant status of saliva in women with normal weight, overweight and obesity. The conclusion of this research that overweight will influence oral cavity status of saliva. The higher of weight of an individual, getting lower of flow rate, volume and $\mathrm{pH}$ saliva. This condition may cause dry mouth and increase the prevalence of caries of the teeth.
\end{abstract}

Keywords: Normal Weight, Overweight, Obesity, Saliva Flow Rate, Saliva pH, Saliva Volume

\section{Introduction}

Overweight is increasing body weight relatively when compared to standard, while obesity is increasing body fat. Health Research showed that increasing proportion of overweight at adults in 2018 is $21.8 \%$. North Sumatera is the highest of Indonesia's province that overweight prevalence was $31.06 \%$. At the moment young age adults are an average of many individuals will begin to realize the dangers of overweight. That is caused at young adults take a change physic, psychology and social status. Most women undergo a diet to reduce overweight by consuming high protein rather than carbohydrate. [1-5]

Average women have more body fat than men. Based on analysis result of obesity prevalence women is higher than men, that is women $32.9 \%$ and men $19.7 \%$. Overweight is influenced $\pm 70 \%$ from environment and $\pm 30 \%$ from genetic. Other factors that caused overweight are social and economy, drugs, and hormonal factors. Overweight can be measured by using Body Massa Index (BMI). Body Massa Index is a statistical measurement from body weight and high of individual that using for classifying individual into categories based on body weight. Overweight can raise serious illness such as diabetes, hypertension and heart. Especially oral cavity, overweight may also influence saliva. [6-8]

Saliva plays an important role in the process of food digestion, regulation of water balance, maintain integrity of teeth, antibacterial activity, buffer and plays an important role for the health of oral cavity. The change of age, environment life and diet can influence saliva. The change of saliva flow rate can cause the change of saliva $\mathrm{pH}$, volume and buffer. Saliva flow rate is parameter to determine normal, high, low saliva flow that stated in $\mathrm{ml} /$ minute. At healthy adult individuals, normal flow rate of stimulated saliva is 1$3 \mathrm{ml} /$ minute, and normal flow rate of unstimulated is 0.25 $0.35 \mathrm{ml} /$ minute. Normal value of saliva $\mathrm{pH}$ is about $6-7$, it depends on flow rate. Individual overweight in addition to having a high fat, it also has high levels of macrophages. 
Macrophages trigger the production of inflammatory cells such as leptin, IL-6, IL-1Ra that will ease the onset of inflammatory process. Occurrence of inflammatory process causes disruption of continuous secretion of saliva and a component of saliva. [8, 9]

Formerly, many research conducted on excess weight associated with systemic diseases and chronic gingivitis that induced periodontal disease in patients. The main problem that comes may be the problem of saliva status which acts to clean the oral cavity. There is still few research on status saliva with body mass index. Hence, this present study were interested about saliva relationship with weight problem women by category body mass index.

\section{Material and Method}

Analytic with cross-sectional design were taken to study about relationship saliva status in overweight women.

Amount of sample was 60 women: 20 persons normal weight, 20 persons overweight, and 20 persons obesity which have age about $20-40$ years old and taking sample method by purposive sampling.

Inclusion criteria of women, normal BMI $\geq 18,5 \mathrm{~kg} / \mathrm{m}^{2}-<$ $25 \mathrm{~kg} / \mathrm{m}^{2}$, overweight $\geq 25 \mathrm{~kg} / \mathrm{m}^{2}-<27 \mathrm{~kg} / \mathrm{m}^{2}$ dan obesity $>$ $27 \mathrm{~kg} / \mathrm{m}^{2}$. The subject was ready to participate in general health research was good, oral hygiene was good.

Taking unstimulated saliva done after getting permission from Research Etic Committee from Faculty of Medicine University of North Sumatera and the subject has signed informed consent to become sample. Collecting data was used with giving questionnaire and checking to research subject.

Retrieval technique of saliva carried out with methods draining, where saliva subject left dripping through the bottom lip into the sampling tube. Subject was instructed to spit.

Measuring saliva $\mathrm{pH}$ was used Hanna Instrument, measuring flow rate and saliva volume used digital scale. Measuring flow rate and saliva volume was done by scaling. The pot or container saliva is weighed before and after collecting the saliva. In 5 minutes, the saliva collected and recorded in a unit of $\mathrm{ml} /$ minutes. The saliva $\mathrm{pH}$ determined by using the saliva $\mathrm{pH}$ indicator based on indicators $\mathrm{gc}$ salivary check buffer measure 5,0-5,8 results will show the condition very acid, 6,0-6,6 will show the condition that acid and 6,8-7,8 will show a normal salivary.

Data result was analyzed by using SPSS version 20.0. Kruskal-Wallis test was used to determine the different average amount of urea level in women with normal weight, overweight and obesity.

\section{Results}

Table 1. Characteristic of subjects, weight and BMI in women with normal weight, overweight and obesity.

\begin{tabular}{lllll}
\hline No & Variabel & N & Weight (kg) & BMI \\
\hline 1 & Normal weight & 20 & $41,5-58,9 \mathrm{~kg}$ & $18,6-24,9 \mathrm{~kg} / \mathrm{m}^{2}$ \\
2 & Overweight & 20 & $52,1-72,8 \mathrm{~kg}$ & $33 \%$ \\
3 & Obesity & 20 & $53,1-118 \mathrm{~kg}$ & $25,1-26,8 \mathrm{~kg} / \mathrm{m}^{2}$ \\
\hline
\end{tabular}

Based on Table 1 shows range on body weight and BMI for each individual with a sample size of 60 .

Table 2. The Average amount of status saliva in women with normal weight, overweight and obesity $(n=60)$.

\begin{tabular}{lllll}
\hline \multirow{2}{*}{ No } & \multirow{2}{*}{ Variabel } & Status Saliva & & \\
\cline { 3 - 4 } & & BBN & Overweight & Obesity \\
\hline 1 & $\mathrm{pH}$ & $7,05 \pm 0,19$ & $6,56 \pm 0,17$ & $6,50 \pm 0,18$ \\
2 & Flow rate (ml/menit) & $0,27 \pm 0,07$ & $0,15 \pm 0,06$ & $0,10 \pm 0,06$ \\
3 & Volume (ml/5menit) & $1.37 \pm 0.36$ & $0.77 \pm 0.32$ & $0.52 \pm 0.31$ \\
\hline
\end{tabular}

Based on the results of the Kruskal-Wallis test obtained significant differences in salivary $\mathrm{pH}$ between the three groups $(P<0.05)$. The higher the weight of each individual the lower the $\mathrm{pH}$ of saliva. With a mean of 6.70 , median 6.60 , the maximum value was $\mathrm{pH} 7.40$ where the maximum $\mathrm{pH}$ value was in the normal group, the minimum value of $\mathrm{pH}$ 5.80 is in the obese group.

Salivary flow rates between the three groups was also significant differences in $(P<0.05)$. The higher the body weight of each individual the lower the saliva flow rate. The mean of salivary flow was $0.17 \mathrm{ml} /$ minute, median of 0.13 $\mathrm{ml} / \mathrm{minute}$, the maximum value of flow rate was $0.35 \mathrm{ml} / \mathrm{minute}$ where the maximum flow rate was in the normal group, the minimum value of $0.01 \mathrm{ml} / \mathrm{minute}$ flow rate lies in obese group.
The salivary volume of this present study, between the three groups was significant difference in $(\mathrm{P}<0.05)$. The higher the weight of each individual the lower the volume of saliva. With a mean value of $0.89 \mathrm{ml} / 5$ minutes, median $0.66 \mathrm{ml} / 5$ minutes, the maximum volume of $1.75 \mathrm{ml} / 5$ minutes where the maximum volume value was in the normal group. The minimum volume value of $0.06 \mathrm{ml} / 5$ minutes was in the obese group.

\section{Discussion}

This research was conducted in women with normal weight, overweight and obesity. This research was conducted to get the average amount of difference levels of saliva status. Methods used in the taking of saliva that is draining method. 
The sample in this study are women comprising 20 persons with 20 persons normal weight, 20 persons overweight and 20 persons are obesity.

Based on the results of the statistical analysis on the research indicates there was significant difference average from saliva $\mathrm{pH}$ in women with normal weight, overweight and obesity. The higher body weight each individual, getting lower saliva $\mathrm{pH}$. The average $\mathrm{pH}$ of saliva obtained in this study is in line with the results of the research of Ain ST (2016), Sarhat RE (2017) and Pannunzio (2010) which shows the average $\mathrm{pH}$ of the saliva on the overweight women in the category (very acidic=5.5-6.0, acid 6.0-6.6, Normal 6.8-7.8) and category BMI (Normal 6.8 and obesity 6.45) on the research of Ain ST, (Normal 7.04 and obesity 6.71) on research Sarhat RE and (7.51 Normal, Overweight and Obese 7.80 7.66) on research Pannunzio. Some of the factors that led to a change in $\mathrm{pH}$ of saliva among others the average flow rate of saliva, microorganisms in the oral cavity and also the body weight. Stimulated saliva generally have a lower $\mathrm{pH}$ than unstimulated saliva. According to Pannunzio (2010), someone who had excess weight who also called overweight and obesity are likely to have a low $\mathrm{pH}$ than having a normal weight, because the concentrations decreased phosphate and peroxidase activity, and decreasing sialkik acid. [10-12]

Based on the results of the statistical analysis on the research indicates there are significant differences in average from saliva flow rate on overweight women. The higher of weight of an individual getting low flow rate saliva. The average saliva flow rate obtained in this study in accordance with the results of the study Muttaqien (2017), Fernanda (2018), Wiharjo (2015), Lindawati Y (2017) that shows the average saliva flow rate in overweight women with category normal $(0.25-0.35 \mathrm{ml} / \mathrm{min}$ ) and category BMI (Normal, Overweight $0.290 .18 \mathrm{ml} / \mathrm{min}$ and obesity $0.15 \mathrm{ml} / \mathrm{min}$ ) on the research of Muttaqien (Normal $0.520 .33 \mathrm{ml} / \mathrm{min}$, Overweight $0.200 .33 \mathrm{ml} / \mathrm{min}$ and obesity $0.120 .33 \mathrm{ml} / \mathrm{min}$ ) on the research of Fernanda, (Normal $0.3 \mathrm{ml} / \mathrm{min}$, Overweight 0.23 $\mathrm{ml} / \mathrm{min}$ and obesity $0.10 \mathrm{ml} / \mathrm{min}$ ) on the research of Wiharjo and (Normal $1.180 .61 \mathrm{ml} / \mathrm{min}$ and obesity $0.740 .21 \mathrm{ml} / \mathrm{min}$ ) on the research of Lindawati Y. Researches that done by Muttaqien, Fernanda, Wiharjo using draining method (unstimulation), and on research using method Y Lindawati spitting (stimulation). The average flow rate saliva on overweight women showed significant differences according to BMI (Normal, overweight, obesity). [8, 9, 13, 14]

The rate of saliva flow in normal weight of having the saliva flow rate is high compared to overweight and obesity. According to Brydon 1 (2008) having of excess weight like (overweight and obesity) having the saliva flow rate who lower than having normal weight. The cause of the flow rate low where the group overweight and obesity showed diminution the parotid gland. Although the adipose high, also is about macrophage that is high. Macrophages will trigger production of cells inflammatory as leptin, IL-1Ra, IL-6 who will facilitate the process inflammatory. The process inflammatory on an overweight induvidual keeps happening thus destruction and break tissue parenchyma glands saliva that contains secretory element of asinus. The secrete secretions and duct secretory who to channel secretions be disturbed and resulting in the rate flow of saliva decline. [9]

This study in line with research conducted by Lindawati $Y$ (2017) category normal body mass index tend to have the flow rate of saliva normal and obesity having a tendency becoming lower saliva even hyposalivation. Modeer T (2010) said increase the mass of a body so index will increase the saliva flow rate, but in samples of adults who are 50 years old with the value of body mass index $>25$ found that the saliva flow rate has declined. In addition, according to Sawair (2009) about unstimulated saliva flow rate on the elderly in Jordan reported that the higher category BMI so the flow rate of saliva are lower. This is in accordance with results also use the method of measurement unstimulated saliva flow. $[8,15,16]$

The analysis of statistics on the research indicated there were differences average that significantly from the saliva volume in overweight women. It means, the higher weight each individual the lower saliva volume. According to Brydon (2008) the cause of low volume on which the group of overweight and obesity show diminution the parotid gland, it is due to the accumulation of adipose salivary glands in the parenchyma, so that the number of cytokines increase, this happen to decreasing the saliva volume or secretion of saliva. The rate relate to volume, with declining saliva flow rate also resulted in the saliva volume. Volume changes can be influenced by the saliva also stimulate received by salivary glands. The stimulation can occur through the mechanical where chewing gum or a severe food, namely chemical stimuli think like acid, sweet, salty, bitter and too spicy, psychic namely stressed that will obstruct the secretion of saliva, can also imagine a tasty food because so the secretion of saliva increases, in example neural stimuli received through the autonomic nervous system both parasympathetic and sympathetic dystrophy or pain stimuli, for example due to inflammation, gingivitis and also because of it will stimulate the secretion of saliva. On previous research no one ever investigated the volume of saliva in overweight women. $[9,17]$

According to Fajrin (2015) the cause of caries is the bacterium Streptococus mutans. Overweight people have a low flow rate which causes the oral cavity to become acidic. If the salivary flow rate decreases, there will be an increase in the number caries that causing bacteria such as Lactobacilus and Streptococcus mutans. Saliva flow rate too contribute to the development of the disease periodontal and oral infections such as candidiasis. In individuals with a salivary flow rate low, bacterial clearance becomes reduced so that colonization of periodontitis bacteria such as Streptococcus constellatus, Eubacterium nodatum, Porphyromonas gingivalis, Actinobacillus actinomycetem comitans in the oral cavity tissue increases. [13]

\section{Conclusion}

In conclusion there are significant different status of saliva 
between normal weight women with overweight and obesity women. The higher of weight of an individual, getting lower of flow rate, volume and $\mathrm{pH}$ saliva. This condition may increase the prevalence of high caries of the teeth.

\section{References}

[1] Segula D. Complications of obesity id adults: A short review of the literature. Malawi Medical Journal 2014; 26 (1): 20-4.

[2] Kaila B, Raman M. Obesity: A review of pathogenesis and management strategies. Can J Gastroenterol 2008; 22: 1.

[3] Sudikno, Syarief H, Dwiriani CM, Riyadi H. Risk factors for overweight and obese in adults in Indonesia. Journal of The Indonesian Nutrition Association 2015; 38 (2): 91-104.

[4] Riskesdas 2013. http://www.depkes.go.id/resources/download/general/Hasil\%2 0Riskesdas\%202013.pdf. 11 Februari 2019.

[5] Riskesdas http://www.depkes.go.id/article/view/18110200003/potretsehat-indonesia-dari-riskesdas-2018.html. 11 Februari 2019.

[6] Diana R, Yuliana I, Yasmin G, Hardins. Risk factors for obesity in young adult women. Jurnal Gizi dan Pangan 2013; 8 (1): $1-8$.

[7] Henuhili V. The genes that cause obesity and the relationship with eating behavior. Seminar Nasional Penelitian, 2010: 1703.

[8] Lindawati Y, Siregar D, Damanik LS. Effect of obesity to salivary flow rate and buffer capacity. Advances In Health Science Research 2017; 8: 333-6.

[9] Muttaqien IA, Kintawati S, Rizali E. Relationship between body mass index (BMI) and salivary flow rate in preclinical students of 2014-2016 Faculty of Dentistry, University of Padjadjaran. Jurnal Kedokteran Gigi Unpad 2017; 29 (2): 918.

[10] Pannunzio E, Amancio OMS, Vitalle MSDE, Souza DND, Mendes FM, Nicolau J. Analysis of the stimulated whole saliva in overweight and obese school children. Review Assosiation Medical Brasil 2010; 56 (1): 32-6.

[11] Ain ST, Sultan S, Gowhar O, Ravishankar LT, Kurma S. Obesity and Salivary Parameters (Flow Rate, Buffer Capacity, and Salivary $\mathrm{pH}$ ) in Children of Moradabad, India. International Journal of Scientific Study. 2016; 4: 3: 25-9.

[12] Sarhat RE. Biochemistry of Serum and Saliva in Obese Individuals with Periodontitis: Case-control study. JODR. 2017; 4: 1: 2-11.

[13] Fajrin FN, Agus Z, Kusuma N. Relationship between body mass index and salivary flow rate (study on the students of the Faculty of Dentistry, Andalas University). Majalah kedokteran gigi Indonesia. 2015; 1 (2): 156-62.

[14] Yas BA. The relation of salivary constituen (urea, calsium and phosphorous) to root caries among overweight and obese adults aged 55-65 year-old at textile factory in mosul city. Tikrit Journal for Dental Sciences 2012; 1: 51-8.

[15] Modeer T, Blomberg CC, Wondimu B, Julihn A, Marcus C. Association Between Obesity, Flow Rate of Whole Saliva, and Dental Caries in Adolescents. Artikles Epidemiology. 2010; 18: $12: 2367-73$.

[16] Sawair AF, Ryalat S, Shayyab M, Saku T. The Unstimulated Salivary Flow Rate in a Jordanian Healthy Adult Population. Journal Clinical Medical Research. 2009; 1: 4: 219-25.

[17] Brydon L, Wright CE, O'Donnel K, Zachari I, Wardle J, Steptoe A. Stress induced cytokine responses and central adiposity in young women. Intern J Obes, 2008; 32: 443-50. 